\title{
The new French regulation on flood protection structures: consequences on risk management
}

\author{
Rémy Tourment ${ }^{1}$, Bruno Beullac ${ }^{1}$, Yann Deniaud ${ }^{2}$, Patrick Ledoux ${ }^{3}$, Frédéric Leseur ${ }^{4}$, Thibaut Mallet ${ }^{5}$, Sébastien Patouillard ${ }^{6}$ \\ ${ }^{1}$ INRAE, 3275 route Cézanne, CS 40061, 13182 AIX EN PROVENCE Cedex 5, France \\ ${ }^{2}$ Cerema, Water, Sea and Rivers, Technopôle Brest Iroise - 155 rue Pierre Bouguer - BP 5 - 29280 Plouzané - France \\ ${ }^{3}$ Cerema, Direction Territoriale Méditerranée, BP 37000 - 13791 Aix En Provence Cedex 3 - France \\ ${ }^{4}$ DREAL Pays de la Loire, 5 Rue Françoise Giroud, 44200 Nantes, France \\ ${ }^{5}$ SYMADREM, 1182 Chemin de Fourchon, VC 33, 13200 Arles, France \\ ${ }^{6}$ DREAL Centre Val de Loire, 5 Avenue Buffon, 45064 Orléans, France
}

\begin{abstract}
Following recent catastrophic floods, France issued in 2007 a first regulation on the safety of dams and levees. In 2014 a new competence has been attributed to local authorities: the management of aquatic environments and flood prevention (abbreviated as "GEMAPI" in French), applied since 2018. Intermunicipal authorities have therefore become legally managers of flood protection systems, with the possibility of transferring or delegating all or part of their new competence to catchment authorities. To be able to fulfil their role, the GEMAPI authorities can raise a specific tax. This change was accompanied by an evolution of the regulation on dams and levees. It makes the distinction between dams, levee systems and the newly identified "hydraulic installations for the temporary retention of water". The performance of structures has now to be clearly defined by the manager. We will present the history of this regulation and analyse what it introduces in the management of the structures, of their safety and of flood risk. We will detail governance and organization, inspection and maintenance, regular risk assessments, flood event management and generally decision for risk management. We will conclude by presenting our point of view on what could still be improved in the future.
\end{abstract}

\section{Introduction - recent floods and need for a regulation}

After a long period without major floods, and particularly without failure of flood defences, France encountered in the last three decades a series of major flood events:

- Floods of Camargue in 1993-1994: multiple breaches and other damages on levees of the downstream Rhône River during two successive floods during this winter. They caused the flooding of the Camargue island (12,500 hectares and 450 flooded houses), causing many damages including the death of livestock;

- Flood of the Aude River in 1999: levee breaches in the Commune of Cuxac. Houses flooded under $2 \mathrm{~m}$ of water, several hundred houses flooded, 5 victims (a total of 25 victims in the department and 35 in the region, not all linked to levees);

- Flood of the Gard and Rhône rivers in 2002: breaches in Aramon and Comps in the Gard department result in the flooding of inhabited areas, causing numerous victims and considerable damage ( $€ 1$ billion damage);

- Flood of the Rhône river in 2003: breaches caused the flooding on the left bank (north of Arles) and the right bank (Camargue Gardoise from the south of Beaucaire to the sea) and about $€ 1$ billion damage in the Rhône delta area;

- Xynthia storm of 2010: the combination of storm surge and high tide levels gave rise to a marine submersion causing severe coastal flooding in some Atlantic regions (mainly Charente-Maritime and Vendée). The consequences were very important: 49 deaths, $€ 2.5$ billion in direct damage and $200 \mathrm{~km}$ of levees in need to be rebuilt;

- Floods of the Agly River in 1999, 2013, 2014 and 2020: numerous damages and several breaches are identified on levees. The resulting flooding caused significant material damage [Tourment, 2018, 1].

These events were the first catastrophic ones after more than a century of absence of major floods involving levee failures. Historically the previously catastrophic events

\footnotetext{
${ }^{a}$ Corresponding author: remy.tourment@irstea.fr
} 
remembered at the national level happened in the $19^{\text {th }}$ century, in particular:

- Floods of the Loire River in 1846, 1856 and 1866: these floods had a discharge return period of about 200 years. These floods caused about 300 breaches or partial breaches along the course of the river;

- Floods of the Rhône River in 1840 and 1856: these floods had a discharge return period of about respectively 250 and 400 years. They caused with the floods of 1841 and 1843 a total 85 breaches and partial breaches, only for the Rhône delta [Mallet, 2019];

- Floods in 1856 in other major rivers (in addition to Loire): Garonne and Yonne.

The fact that flood defences often fail to perform, and even breach, during a major river flood or coastal storm is an observation which lead after analysis of the situation that they were not well enough managed and not maintained in a sustained way, in addition to the fact that these defences are ancient structures and not built according to current engineering good practice.

Starting with the aftermath of the Camargue floods of 1993-94, and up to after the Xynthia storm of 2010, the French State has integrated the necessity of a better reliability of the flood defences; it has initiated a series of measures to insure their performance in the long term. Local authorities also began to be involved in different ways in flood risk management, including in relation to flood defences. We will present in this paper the evolutions in regulation and management on levees but also on the other types of flood defence structures. We will make the distinction between the evolutions that happened before and after the important introduction of the GEMAPI competence that will be presented in section 4 .

There are two main types of flood protection structures: levee systems that prevent water to reach protected areas (Fig. 1) and retention structures (dams or offline reservoirs) that temporarily store water and, by doing so, reduce the river discharge downstream of their location (Fig.2). Not only these two types of structures have a different effect but they also have a different limit, a water level in the case of a levee system, and a volume in the case off a retention dam. Diversion canals can also help mitigate floods, often in association with levees and/or retention structures [Tourment, 2016, 1]. The paper will consider these different types of structures wherever appropriate.

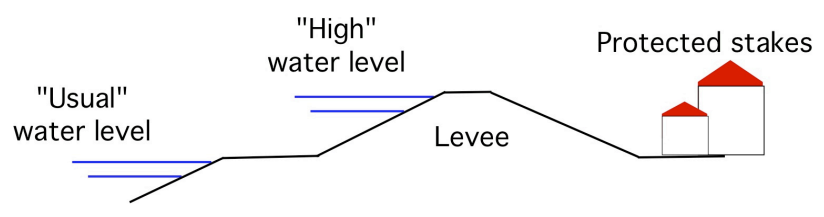

Figure 1. Levees prevent water to reach a protected area [Tourment, 2017]

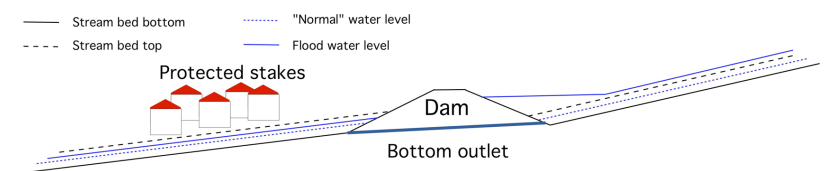

Figure 2. Flood retention dams reduce the downstream water discharge (and level) [Tourment, 2017]

\section{History of the previous regulation}

This section will present the regulation specific to hydraulic structures, some general underlying regulation that pre-existed to the introduction of the GEMAPI competence.

\subsection{Code Civil and responsibility of the owner}

According to the French "Code Civil", a fundamental text that is the foundation of French civil law and, more broadly, of all French law since the early $19^{\text {th }}$ Century, every building or structure is under the responsibility of its owner. So, if a dam or levee breaks and causes some damage, the owner's liability will be the first one to be looked for in the first place. Such damage will occur mainly in the case of a natural flood or storm event in the case of flood defences, but may also happen at any time in the case of structures permanently retaining water (dams, canals...).

In the case of old ("orphan") levees and sometimes dams, it may be difficult to identify the owner of the structure, as tracing its origin can lead to many uncertainties. In this case, the owner of the right-of-way of the land on which the structure is located will generally be considered to be its owner, unless a contract can be found, transferring the property to its builder. In the case of levees, which can be very long and where the right-of-way of the land can have multiple (hundreds or more) owners, the responsibility is even more difficult to attribute.

However, other entities can be held accountable in the case of damages caused by a structure failure: engineers and constructors having worked on the structure, but also in general the French State and the Mayor of the Commune, both in charge of the population safety.

\subsection{The 1807 law on the draining of marshes}

According to the law of $16^{\text {th }}$ September 1807 , building protection levees against sea, rivers or streams is the responsibility of local residents and there is no obligation of protection against flooding by the public authorities.

\subsection{The 1970 circulaire $^{a}$ on dam safety}

Following the catastrophic dam failure of Malpasset in 1959 [French Ministry for Sustainable Development, 2009], major dams ("relevant to public safety") were submitted to a series of measures, starting at the beginning of the project, and all along the dam life cycle, to ensure its safety. These measures, defined in a "circulaire" that the local State services had to apply, while maintaining a database on the existence and characteristics of such dams, included the review of the projects by a national standing committee, regular visual inspections, annual detailed inspections and assessments, a decennial review including a complete

a In France, a Circulaire is an administrative instruction to state services that these have to implement. Strictly legally speaking, it is not enforceable against third parties, but in many cases it is applied, via prescriptions from state services. 
inspection involving if necessary the emptying of the reservoir and the keeping of a "dam file" up to date.

\subsection{Authorization of hydraulic structures}

In order to build a structure in relation to water, including dams and levees, the "Water Law" of 1992 demands that a file is submitted to the State authorities to check the administrative and technical compliance.

\subsection{The 1999 circulaire on the "census" of levees}

In 1999 the State has initiated, via a circulaire, a national "census" of levees, in order to assess the levees portfolio, its performance, the overall associated flood risk and necessary measures to reduce it. Applied at the local level by State Services, it first relied on a local database that had to be integrated at a national level, then it was done through a national online database, BarDigues. An analysis of the data, performed in 2005, concluded in the existence of about $9000-10000 \mathrm{~km}$ of levees $(8000-9000$ on rivers and 10001300 coastal), thousands of owners and of managers and about 2 million people living in protected areas. The major conclusions that could be drawn were $1 /$ that many levees were in need of refurbishment and 2/ that management was generally not done at the right scale and without adequate resources (in both funding and staff). So far the order of magnitude of the length of existing levees has been confirmed and the current database, SIOUH, does not give a more precise appreciation of the levees portfolio. On the other hand, the management of levees has widely evolved, as we will see later in this paper.

\subsection{The 2002 circulaire on embankments in flood prone areas}

As part of a circulaire on embankments in flood zones, the State introduced the need to install safety spillways on levees. This circulaire has now been abrogated, but the principles of having levee systems that are resilient to overtopping remains implied in various items of the technical regulation.

\subsection{The 2003 circulaire on levee safety}

On the basis of this census, the State set up in 2003 a control system of levees "interesting public safety", similar to the one from 1970 for dams. Specifically to the levees, an initial safety assessment has to be performed in addition to the regular inspections and assessments.

\subsection{The 2007 decree on the safety of hydraulic structures}

Then, having found that circulaires were not the right legal tool to impose measures to third parties and that the safety of dams and levees could follow a similar safety framework, in 2007/2008, the State decreed ${ }^{b}$ rules that are imposed on the owner and/or manager of dams and levees. These rules are proportionate to the importance of the stakes. Thus four classes of levees were created according to the number of protected people and the height of the levees, and four classes of dams according to volume of the reservoir and the height of the dam. The respective roles of the State services and of the owner or manager of the structures were clarified.

Thus, the owners or managers (according to the case) of hydraulic structures were required, with a period depending on the structure's class when appropriate:

- to establish and to keep up to date a technical file describing the structure, its design and the modifications made to it;

- describe the organization for its maintenance, its surveillance (monitoring only being mandatory for dams);

- keep a record (a register, mandatory for dams only, recommended for levees) up to date, including all events, inspection, monitoring, maintenance;

- periodically prepare an inspection and monitoring report;

- periodically carry out an in-depth technical visit and a safety assessment;

- periodically carry out a hazard study ${ }^{\mathrm{c}}$ (a specific format of a risk analysis, defined in the regulation) [Tourment, 2016, 2];

- to declare events of importance for hydraulic safety.

Consultants preparing a project or conducting a safety assessment or hazard study have to be approved by the State after having made the proof that they are competent in hydraulic structure engineering.

The principles on the roles of the main actors (owner/manager, Commune, State, consultants) are presented in Table 1.

This regulation (decree and associated orders) clearly defined the role of the dams and levees owners and managers, in terms of technical obligations, and of the State services in terms of controlling the actions of the owner or manager. Its purpose was to ensure that these controlled hydraulic structures would not fail and present a public hazard. Its major flaw was that it could not be applied in the case of "orphan" structures for lack of a responsible entity; in the case of a dam it generally is easy to find who the owner is and by consequence who is in charge, but in the case of levees it is much more problematic (cf. 2.1). Another flaw in regard to levees, was that it did not clearly defined at what scale a "levee" had to be defined, while the flood protection is ensured at the level of a consistent levee system, and not at the level of a levee segment.

b Décret n 2007-1735 du 11 décembre 2007 relatif à la sécurité des ouvrages hydrauliques. Décrets, executive orders based on laws, are enforceable against third parties, like Arrêtés, which are also administrative acts, based on Décrets.

c Etude de dangers, in French 


\begin{tabular}{|c|c|}
\hline Actors & Roles \\
\hline $\begin{array}{l}\text { Owner or } \\
\text { manager }\end{array}$ & $\begin{array}{l}\text { - fulfil the obligations set out in the } \\
\text { administrative authorization act } \\
\text { - inspect and maintain the structure in } \\
\text { all circumstances, including during } \\
\text { hydrometeorological events } \\
\text { - declare, as soon as possible, to the } \\
\text { prefect any event concerning a structure } \\
\text { and jeopardizing the safety of people }\end{array}$ \\
\hline $\begin{array}{l}\text { Approved } \\
\text { consultants }\end{array}$ & $\begin{array}{l}\text { - design projects for construction or } \\
\text { substantial modification of a structure } \\
\text { - carry out hazard studies and detailed } \\
\text { assessments }\end{array}$ \\
\hline $\begin{array}{l}\text { Mayor of the } \\
\text { Commune }\end{array}$ & $\begin{array}{l}\text { - inform the citizens of the risks in the } \\
\text { Commune } \\
\text { - take risks into account in urban } \\
\text { planning documents, based on the } \\
\text { hazard maps developed by the State } \\
\text { - ensure flood warning } \\
\text { - organize emergency management in } \\
\text { the case of a flooding of the Commune }\end{array}$ \\
\hline State & $\begin{array}{l}\text { - identify existing dams and levees, } \\
\text { their characteristics and their owner and } \\
\text { manager } \\
\text { - authorize the building and operation } \\
\text { of the structure and emit prescriptions } \\
\text { - control the proper execution of the } \\
\text { owner or manager obligations } \\
\text { - publish risk knowledge by means of } \\
\text { hazard maps and edict prescriptions for } \\
\text { municipal urban plans } \\
\text { - flood forecasting on monitored rivers } \\
\text { - organize emergency management in } \\
\text { the case of a major event }\end{array}$ \\
\hline
\end{tabular}

Table 1. Roles of the main type of actors in the 2007 regulation

\section{Evolution of the management of levees}

This section will present some example of the evolution of flood defence management organizations before the introduction of the GEMAPI competence. In the case of levees and levee systems, this was often the result of local flood events, or of a national regulation as a stimulus. As the 1993-94 floods in Camargue and many of the following events demonstrated, the most important factor in flood defences ability to perform when an event happens is to have an efficient and sustainable management. Managers have to continuously maintain the levees in a good state and also have to be able to perform emergency repairs to avoid breaches during an event.

\subsection{The South of the Rhône river}

Flood defence in the Rhône river delta dates back to the 12th century, date of construction of the first levees. But the floods of 1840 were the real starting point for a State policy in terms of protection against flooding from the Rhône, with the creation in 1840 of a special department for the Rhône. Engineers draw up plans from this time and built the first socalled "unsubmersible"d levees. The floods of May 1856 (similar to those of 1840) accelerate and amplify the completion of the structures. The State is involved in the design, construction and financing of the structures.

Once the levees have been built, maintenance has been entrusted to associations of local landowners (Associations Syndicales Forcées, ASF), the Rhône Special Service being limited to controlling the structures. This organization will last until 1987 in Gard and 1996 in Bouches du Rhône ${ }^{\mathrm{e}}$. On the Gard side, in 1985, the ASF was dissolved and replaced by the Intermunicipal Union of the Levees of the Rhône from Beaucaire to the Sea (Syndicat Intercommunal des Digues du Rhône de Beaucaire à la Mer - SIDR). This Union brought together the Communes flooded in 1840 and its mission was to maintain the levees on the right bank of the Rhône and the Petit Rhône. On the Bouches-du-Rhône side, the ASF were dissolved following the floods of winter 1993-94, and replaced by the Intermunicipal Union for the Management of Dykes of the Rhône and the Sea (Syndicat Intercommunal de Gestion des Digues du Rhône et de la Mer - SIDRHEMER), which was joined in 1999 by the Provence-Alpes-Côte d'Azur region and Bouches-du-Rhône Département. The Mixed Union ${ }^{f}$ then took the name of SYMADREM (SYndicat Mixte d'Aménagement des Digues du Rhône Et de la Mer).

The flood of December 2003 (centennial) highlights the need to have a comprehensive management of levees in the Rhône Delta. The municipalities of the Gard side accompanied by the Occitanie region and the Gard department joined in 2005 the SYMADREM, which became an Interregional Union and took the name of Syndicat Mixte Interrégional d'aménagement des digues du delta du Rhône et de la Mer while retaining the same acronym SYMADREM.

It will have taken 800 years to move from local and private management of flood prevention to global and public management.

\subsection{The Agly river}

The downstream part of the Agly River [Tourment, $2018,1], 13.2 \mathrm{~km}$ of watercourse, located in a low maritime plain in the department of Pyrénées Orientales, has levees on its two banks. Floods in this part of France are frequent and violent. After 5 floods in 3 weeks in 1965, an ambitious development project was born at the end of the 1960s. The works were carried out from 1969 to 1974, under the supervision of the Department of Pyrénées-Orientales and with financial support from the French State up to $60 \%$. In

$\mathrm{d}$ This denomination is now avoided as it is ambiguous (= will not be overtopped or must not be overtopped?) and as it may give a false sense of safety to populations living behind these levees e The area depends of these two different administrative

"Départements", themselves being part of a different administrative "Région".

f A Mixed Union is an union of different types of local authorities (Communes, Intermunicipalities, Départements, Régions, ...) and possibly other legal entities 
the early 1990s, the Department built a large flood retention dam, some $30 \mathrm{~km}$ upstream on the main course of Agly. From 1982 to 2007, the levees of the low plain of Agly were managed by an Intermunicipal Union, which later became a Mixed Union, grouping together the 6 neighbouring municipalities. From 2008, the management of the levees was taken over by the Pyrénées-Orientales Department, which also owns part of the structures as well as the flood retention dam.

\subsection{The Breton Marsh}

The Breton Marsh is the result of the natural filling of the Bourgneuf Bay. The part of this marsh in the Vendée Département is in contact in the west with the Atlantic Ocean, in the municipalities of Bouin and Beauvoir. The town of Bouin was an island until the middle of the 19th century (Fig. 3).

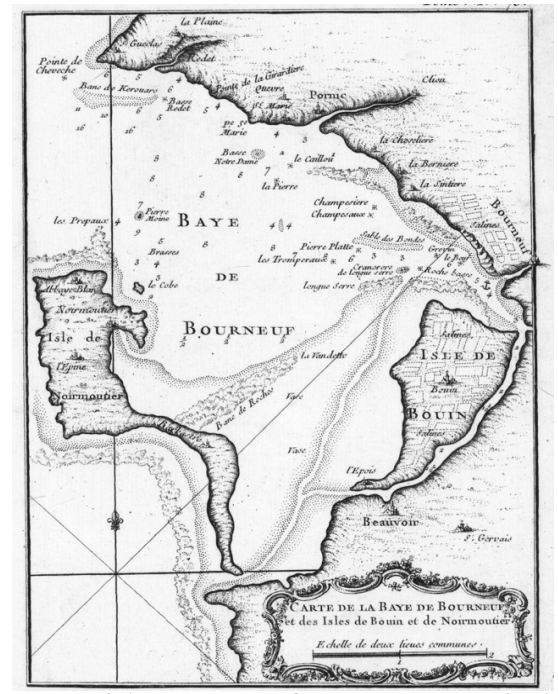

Figure 3. Map of the Bourgneuf Bay (Jacques-Nicolas Bellin, 1764)

The areas reclaimed from the bay have been protected from marine hazards by coastal levees. They were built until the 1960s, as part of local reclamation programs. In the 18th century these reclamations were carried out with authorizations that placed the supervision and maintenance of the levees at the expense of the owners of the new land, organized in the form of associations of local landowners (ASF, or Associations Syndicales Forcées). In the 19th century it was a private company that took over the management and construction of the levees.

Because of funding difficulties and because the levees also protected homes, the municipalities of Bouin and Beauvoir took over with the help of the Département in the 1950s. In 1982, the municipalities and the Départment of Vendée joined forces to create the "Mixed union for defence against the sea" (Syndicat mixte de défense contre la mer, SMDM), also including an association of landowners. The SMDM facilitated the financial involvement of local authorities in inspection, maintenance and investment on the levees. The Département also assisted in the procurement of studies and works.
It was therefore the SMDM which was the manager of the levees during the Xynthia storm and which launched the first levee repair operations. It was also the SMDM that met the expectations defined in the 2007 decree. But the SMDM having only one employee, it was difficult for it to meet all of its obligations.

\subsection{France Digues and CFBR}

On a less administrative level, but still important in terms of organization, professionals involved in flood defence structures started to organize in networks to share experience and initiate progress.

Created in 2013 at the initiative of three of the main levee management organizations in France, SYMADREM, AD-IDR and DREAL Centre - Val de Loire with a support from Irstea (now INRAE), France Digues ${ }^{\mathrm{g}}$ is an association of levee managers that benefits from the financial support of the French Ministry in charge of Environment. Its purpose is to structure and professionalize the levee manager's profession. It offers its members, among other things: access to a large network of levee managers, participation to technical sessions on themes targeted to the needs of its members, regulatory watch; technical documents and notes, various meetings (Technical Committee, thematic working groups, etc.), privileged access and assistance in the use of SIRS Digues software, a website in which professionals and experts can participate via a forum. It currently has 64 members and 5 associate members (organizations in relation to levees and levee management which are not actual levee managers).

CFBR $^{\mathrm{h}}$, French national committee on large dams, aims to promote progress in the design, construction, maintenance and operation of dams and levees, through the exchange of information between its members. It brings together professionals from all types of organizations: owners, managers, consultants, constructors, researchers and Administration. Each year, it organizes a Technical Symposium open to the entire profession and leads national think tanks responsible for drawing up recommendations. The Committee actively participates in the work of the International Commission on Large Dams (ICOLD ${ }^{\mathrm{i}}$ ). It participates in General Assemblies and Congresses of ICOLD by presenting reports on the issues on the agenda. It is represented in the Technical Committees of the ICOLD and participates in the drafting of the bulletins published by the ICOLD which constitute the international reference in the profession. CFBR integrates the issue of flood protection levees since January 2012. In addition, ICOLD created a technical committee on levees in 2017 and a question at the 2018 Congress related to levees: their consideration within these committees is now acquired at national and international levels.

France Digues and CFBR are not in competition: France Digues members are organizations, while CFBR members are professional individuals and France Digues objectives

g http://www.france-digues.fr/

h https://www.barrages-cfbr.eu/-Home-.html

i https://www.icold-cigb.org/ 
are more practice oriented and centred on the management, while CFBR objectives are more oriented towards engineering knowledge, both technical and scientific, and deal with all aspects related to hydraulic structures. Nonetheless, it can be noted that their interest in levees and flood protection structures started in the same recent period, when the evolutions described in this paper became a national trend.

\section{The GEMAPI competence and the role of the local managers}

\subsection{A regulation on governance}

Having found difficulties in many cases to actually apply the 2007 regulation on the safety of hydraulic structures in the case of levees, the State has acknowledged the need for a clear attribution of the responsibility for their management.

New laws on the organization of local authorities $\left(n^{\circ}\right.$ 2014-58 of January 27, 2014 and $n^{\circ} 2015-991$ of August 7, 2015), modified by a specific law ( $\mathrm{n}^{\circ} 2017-1838$ of December 30, 2017), defined the management of aquatic environments and flood prevention (Gestion des Milieux Aquatiques et Prévention des Inondations, GEMAPI) as a new competence entrusted to Intermunicipal level (établissement public de coopération intercommunale EPCI), to be applied from January 1, 2018. The aim of the competence is to build, when not yet existing, a strong contracting authority in charge of the management of aquatic environments and flood prevention, to promote a global vision of flooding issues and to push towards water management at catchment or sub-catchment scale. This larger scale makes possible to link flood management and water management with spatial and land use planning, which are already competences for the municipal and Intermunicipal levels, and thus integrate water into projects of territory.

The GEMAPI is defined by the following four items:

- watershed management of a hydrographic catchment or fraction of catchment;

- maintenance and development of a watercourse, canal, lake or body of water, including access to this watercourse, this canal, this lake or this body of water;

- defence against floods and the sea;

- natural protection and restoration of sites, aquatic ecosystems and wetlands as well as riparian vegetation.

- In particular, defence against floods, from fluvial or maritime origin, involves the management of flood mitigating structures. These structures are classified in two different categories (see section 5):

- levee systems,

- hydraulic installations for the temporary retention of water.

To finance this new competence, the EPCI can impose a specific tax to the people and businesses in its territory, which cannot exceed a total amount of 40 euros per inhabitant and per year.

To implement its actions, the GEMAPI authority must assess the challenges of its territory by means of a in-depth diagnosis in order to define a territorial project that elected officials will carry. The main issues for the exercise of the jurisdiction are:

- what rivers are present on my territory? What is their mobility space? What kind of coastline does border my territory? With what kind of tide and swell regime? What coastline mobility?

- how do sediments move in rivers or on the coast? In which state are the banks and the dune cords?

- what hydraulic structures exist on my territory? Who manages? What is their condition? What areas do they protect?

- how vulnerable is my territory?

- are there watercourse maintenance programs in my territory? Are there flood prevention action plans (see section 6)? Who conducts them? Who funds them?

Intermunicipalities may form a wider union who will ensure the exercise of the competence, and will receive the dedicated taxes. They also can delegate the exercise of the competence (all or part of it) to establishments of public water planning or territorial water basin management. Based on voluntary decisions, other competences can be devoted to the unions in order to allow the adhesion of the Department of regional Councils.

Easements can be applied on private levees. Owner's union association can continue to manage levee systems or can delegate their management to the competent GEMAPI authority. The different choices depend on the respective wishes of the union and the competent authority and results in a contractual agreement.

Infrastructure embankments, with other primary purposes (road embankment, railway embankment, etc.), can also be integrated into the flood defence levee systems. If the competent authority finds that the infrastructure embankment and other pre-existing devices is necessary for efficiency of the flood defence system, an agreement or contract must formalize the obligations of each managers including financial aspects.

A major point of the GEMAPI competence is the liability limitation. With regards to levee systems, the competent authority for GEMAPI must define systems associating a levee system, the protected area and the related protection level. As long as the competent authority complies to legal and regulatory obligations relating to the maintenance, operation and safety of works composing the flood protection levee systems, its liability cannot be committed in case of flooding caused by a natural event beyond the protection level.

Nevertheless, the GEMAPI authorities that manage flood levee systems, have the obligation to inform the authorities responsible for emergency management (Mayor of the Commune and Prefect of the Département) of the situation of their structures in all circumstances and to ensure their management until their limit is reached.

Finally, it should be noted that the French state is itself a levees owner and in particular on a large part of the Loire River major levee systems. In this context and to accompany the evolution of management structures, the law on the organization of local authorities provided that the State services could continue to manage levees on behalf of the Intermunicipalities for 10 years. 


\subsection{Evolution of management organizations}

We present in this section the evolution of the management of the structures presented earlier in sections 3.1 to 3.3 .

\section{The South of the Rhône river}

SYMADREM is now managing, by transfer of the GEMAPI competence from the different EPCIs on its historical territory, all levees on the downstream Rhône river. In 2018, the EPCIs replaced the municipalities as members of the union, to comply with the GEMAPI related laws. In accordance with these laws, the two regions and the Gard department have left the union while maintaining their efforts to support the investments of SYMADREM. The union now regroups the Bouches du Rhône department and 6 Intermunicipalities. With the new competence, SYMADREM is now the sole authority responsible for sea defence across the entire delta, which has enabled it to work on a coastal strategy to deal with climate change, a vital element for this reclaimed territory.

SYMADREM also is responsible for water evacuation after flooding, which was previously insured by multiple organizations

\section{The Agly river}

Levees of the Agly river are managed since the beginning of 2020 by a Mixed Union (Syndicat Mixte du Bassin Versant de l'Agly - SMBVA) to which the seven different EPCIs of the river catchment, among which two have levees on their territory, have transferred the GEMAPI competence with the exception of the defence against the sea. The laws governing GEMAPI required this transfer of competence from the Département of Pyrénées Orientales (CD66), while local actors judged that the management by the Department was satisfactory. This evolution was accompanied by the recognition of levees as a levee system in July 2019, under the management of CD66.

When the recognized levee system was transferred to SMBVA, regulation as well as physical analysis required the inclusion of other levees and structures involved in flood defence or management, such as road, highway or railway embankments and levees not yet included in the levee system (particularly levees in second line of defence). These additions turn out to be more complicated to implement, as they involve several managers (Département as roads manager, Vinci as highway manager, SNCF as railway manager, Intermunicipalities, private owners...) with whom to negotiate. The difficulties encountered are not all resolved, shared management issues and responsibilities have to be clarified and reflection continues to find the best solution to define complete protection systems. For now, the recognized levee system is the one defined under the management of CD66.

The level of protection of this levee system was determined considering that the Agly dam - not transferred to SMBVA - retained part of the floods. It was therefore necessary to guarantee this participation of the dam in flood protection, as it has different functions: flood retention, water supply to the river during low water season and irrigation. A difficulty was to be able to share the responsibility of these different functions between CD66 and SMBVA as managers of different uses for the dam, corresponding to a different reservoir volume. The dam was classified in July 2019 as hydraulic installation for the temporary retention of water $(\mathrm{AH})$, simultaneously as the classification of the levee system, and an agreement was signed on the between SMBVA and CD66 which remains operational manager of the dam, while SMBVA is responsible of flood protection in its territory.

The new organization of SMBVA does not yet completely replace the old one: the SMBVA currently has 1.5 agents for supervising and managing its $26 \mathrm{~km}$ of levees, and the total workforce of 6 people could turn out to be insufficient in the event of a major flood creating damage on the levee system or in the event of major refurbishment works. Therefore, SMBVA hires contractors to realise technical tasks as maintenance and refurbishment works, but emergency repair works too. If necessary, SMBVA could request technical support of Communes and Intermunicipalities. During the last flood on January 2020, crisis management but also emergency works have been done in short time and efficiently. Other solutions can be considered to strengthen the capacities of SMBVA (pooling with other structures, etc.).

\section{The Breton Marsh}

In accordance with the NOTRe law, the Vendée Département had to leave SMDM in 2016. This caused funding issues for the union, with only the two Communes left to fund the management of flood defences. The Communes decided to dissolve SMDM in 2017, which was made possible because of the new GEMAPI competence, as this dissolution could not be done without another manager taking charge of levee management. The EPCI "Challans Gois Communauté" therefore anticipated the implementation of GEMAPI, and took over the management of the levees.

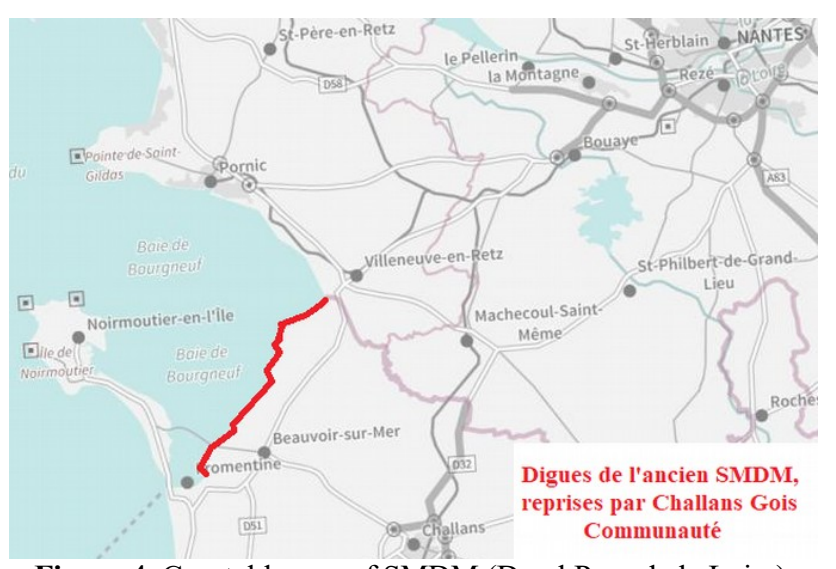

Figure 4. Coastal levees of SMDM (Dreal Pays de la Loire)

Challans Gois Communauté first put one person (technical staff) in charge of this new mission, in addition to his previous environmental missions. Administrative and financial departments of the Communauté were also involved. Then it recruited another technician to monitor the levees and manage the maintenance. Chalans Gois Communauté also took over project management of various ongoing works and studies (including the general study for the reclassification of the various levees in one or more 
levee system). Experience has shown that the recruitment of a new staff member is necessary.

\section{The current technical regulation on flood defences}

In parallel to the regulation defining the governance of flood defence structures (see section 4.1), the related technical regulation (see section 2) also evolved. The basis for this evolution was a new Décret ${ }^{j}$, followed by subsequent other Décrets and Arrêtés. There are now three different legal categories of hydraulic structures:

- dams,

- levee systems,

- hydraulic installations for the temporary retention of water (called in short "aménagements hydrauliques" or usually AH in French),

with three classes for dams and levee systems. Like in the previous regulation, dams are classified according to their height and the volume of their reservoir, but with different limits between classes. Both levee systems and AHs are flood defence structures. Levee Systems are classified according to the number of people living in the protected area. AHs can also be classified as dams, depending on their height and volume. Physically, on rivers, an $\mathrm{AH}$ can either be a flood retention dam, an offline reservoir or a complex system involving reservoirs, canals and levees (figure 5).

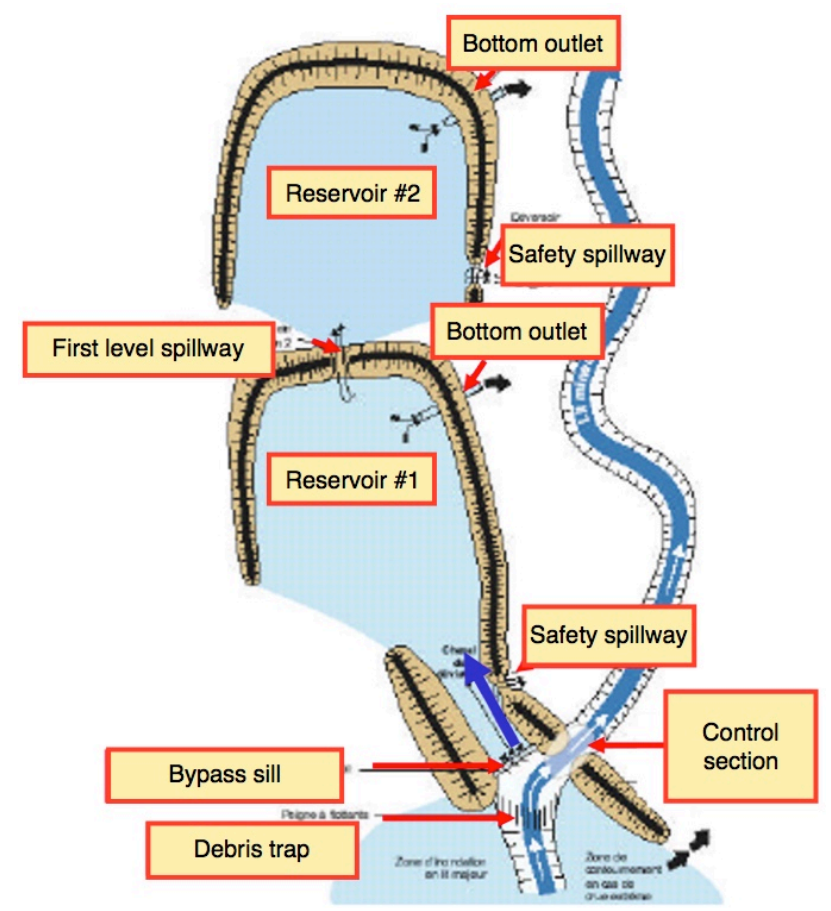

Figure 5. An example of hydraulic installation for the temporary retention of water

Along the coast, an $\mathrm{AH}$, necessarily associated with a levee system, can either store sea water to prevent it to reach the protected area (fig. 6a), or store runoff water from the

j Décret n 2015-526 du 12 mai 2015 protected area coming from rain or from overtopping of the protection system (fig. 6b).

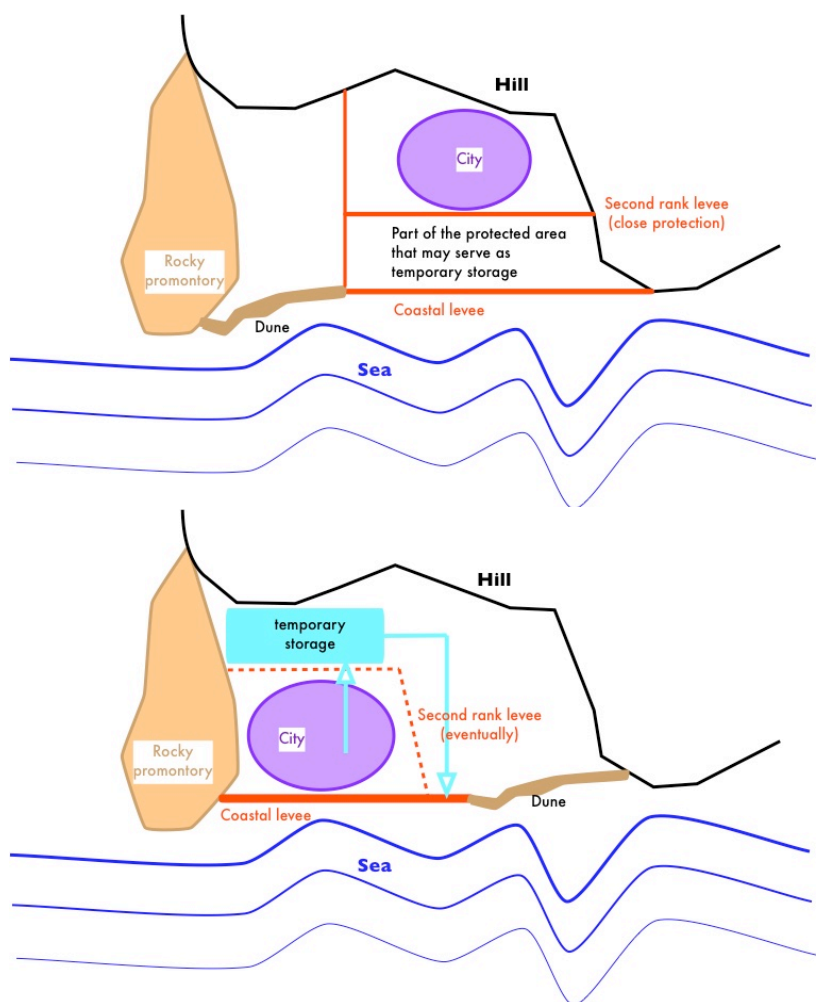

Figures 6 a\&b. Examples of coastal hydraulic installations for the temporary retention of water $(\mathrm{AH})$

Basically, the obligations that had been set in 2007/2008 for levees (see section 2) can be transposed to levee systems with a few adaptations. The main differences between the previous regulation framework (section 2) and this new one are:

- the new AH category, acknowledging the role water storage structures or systems can play regarding flood defence, as single function or in association with others, like for instance multifunction dams;

- levee systems are now considered, in place of levees (which definition was not obvious in terms of limits, and which also, in most of the cases, did not actually perform their protection function all by themselves);

- while for dams the main objective of the regulation still is to ensure the safety of the structure, for flood protection structures its main objective is to define and demonstrate the effective flood protection (this demonstration obviously implies to also assess the structure performance and safety),

- consequently, with regard to these different main objectives, the initiative of the classification of dams remains in charge of the State, while the initiative of the classification of flood protection structures falls to the GEMAPI authority. In both cases the actual classification remains under State control;

- hazard studies for flood protection structures have to explicitly display their objective in terms of protection (protected area and level of protection) and justify it via their hazard study. They now incorporate the regular 
periodical assessment, which previously was a separate requirement;

- levee systems also are submitted to the obligation of having a register;

- the frequency of the various periodical obligations, related to the structure class, are changed.

The hazard studies of levee systems have a completely new format, by comparison to the previous hazard studies for levees. A levee system hazard study is placed at the center of the knowledge of the system and its environment (water side and protected area). It must present the system and its environment and justify its expected performance in all circumstances from a risk analysis process. The detailed content is fixed by ministerial Arrêték. The document constituting the hazard study is broken down into three parts:

1. a non-technical summary, which function is to present the conclusions of the study in terms of protection level, delimitation of the protected area and risk scenarios for water inflows;

2. document $\mathrm{A}$, the function of which is to present a summary of the technical elements detailed in document B;

3. document B details the analyses which make it possible to assess and demonstrate the performance of the levee system.

\section{Other regulations and related instruments for flood risk management}

Owners of Levee system have to take in account and to fit in the national framework for flood prevention. Flood risk management competences are split between government and local authorities. At the government level, the main prerogatives are the national and regional flood risk assessments (flood hazard maps and risk evaluation), the control of urbanization in flood prone areas through flood risk prevention plans (PPRi), flood alert and early warning through a network of flood forecasting services on the main rivers, crisis management and rescue for large scale crisis, and safety control of the levee systems and other hydraulic structures. At the local authority level, the prerogatives encompass land use planning taking into account flood risks, citizen information about flood risk in the municipality, crisis management at the scale of the municipality under mayor responsibility, management of levee systems for flood protection.

Since 2014, a national strategy for flood management aims to mobilize everybody on shared priorities and to plan and prioritize public funding on the more efficient actions. It defines three main goals to achieve: $1 /$ to increase the safety of the population; 2/ to reduce damage costs; $3 /$ to shorten the time delay for the post disaster recovery in affected areas. In the implementation of the European flood risk directive, a national preliminary flood risk assessment (PFRA) was conducted at national level. 122 areas of potential significant flood risks (APSFR) were identified, among them 16 have been judged with a national impact. In

k Arrêté du 7 avril 2017 NOR: DEVP1701396A all of them flood hazard maps and flood risk maps have been produced.

For each regional hydrological district, specific objectives have been defined through flood risk management plan (FRMP). Measures are classified by topics: 1/ objectives and measures form the river basin management plan, 2/ observations, forecast and information, 3/ territorial vulnerability reduction; 4/ Education, resiliency, awareness. The purpose of these risk management plans is to implement the priority of the national strategy, to prioritize the measures and to allocate public budget on efficient and urgent actions. They also support the strategic vision of the treatment of areas potentially at risk of significant flooding (APSFR) inside the district. Inside these areas, local strategies for flood risk management are implemented with all stakeholders.

These strategies can lead to flood prevention action plans (PAPI) that help local government with technical and financial supports.

Flood prevention action plans have to deal with the seven axis of the French policy to reduce the risk from disasters: 1/ Knowledge and consciousness, 2/ Observation, forecast and information, 3/ Warning and crisis management, 4/ Spatial planning, 5/ Territorial vulnerability reduction, 6/ Slowing down the flows, 7/ Management of the levees. This last axis is of major interest for the levee managing authority, as it is the main source of public financial support.

Last but not least, a major tool is implemented under government cover, for improving territorial planning in order to reduce flood impact on urban areas: the risk prevention plan (PPR). On the basis of hazard maps, buildings are forbidden or authorized under constraints through requirements of specific measures for their construction.

Finally, in the case of an event, forecast and flood warning are carried out by state services on a national or regional scale on the monitored river networks. The Mayor of a Commune is in charge of emergency management, on the scale of the municipality's territory, through the activation of the municipal emergency plan (Plan Communal de Sauvegarde - PCS). If the event is of major impact and affects several municipalities, the Préfet, who is the state representative at local level of a Département, coordinates emergency response at regional scale. In all cases, the levee system or AH or dam manager must inform the emergency and state services of the behaviour of its structures in all circumstances and have to warn them of any risk of failure and potential consequences.

\section{Conclusions, perspectives}

The succession of flood events in France since the 1990s has initiated a general in depth awareness of flood risk and of the importance of a good management of flood protection structures. This awareness has lead in parallel to evolutions and improvements of local governance of levee systems, and to an evolving regulation regarding these structures and their management. Beyond local managers and State Administration, the rest of the community around hydraulic structures, engineers and researchers, has also followed this 
trend, producing and sharing knowledge and good practice in order to improve their management, and overall their performance and safety.

The creation and the evolution of a specific national regulation on flood protection structures has accompanied, and sometimes initiated, this awareness and improvement of the management, performance and safety. Beyond this simple statement we can make the following comments on these evolutions and the resulting regulation:

- In any part of French territory there is now clearly an authority in charge of the definition of flood protection and of the management of the structures. This solves the previous situation with many "orphan" levees.

- There is now a clear distinction between the responsibilities of the State and those of the local (Intermunicipal or catchment) authorities in charge of flood risk management (figure 7). The State services in charge of the safety of hydraulic structures, which control dam safety under the responsibility of their owners, now also controls levee systems and hydraulic installations for the temporary retention of water under the responsibility of their managers.

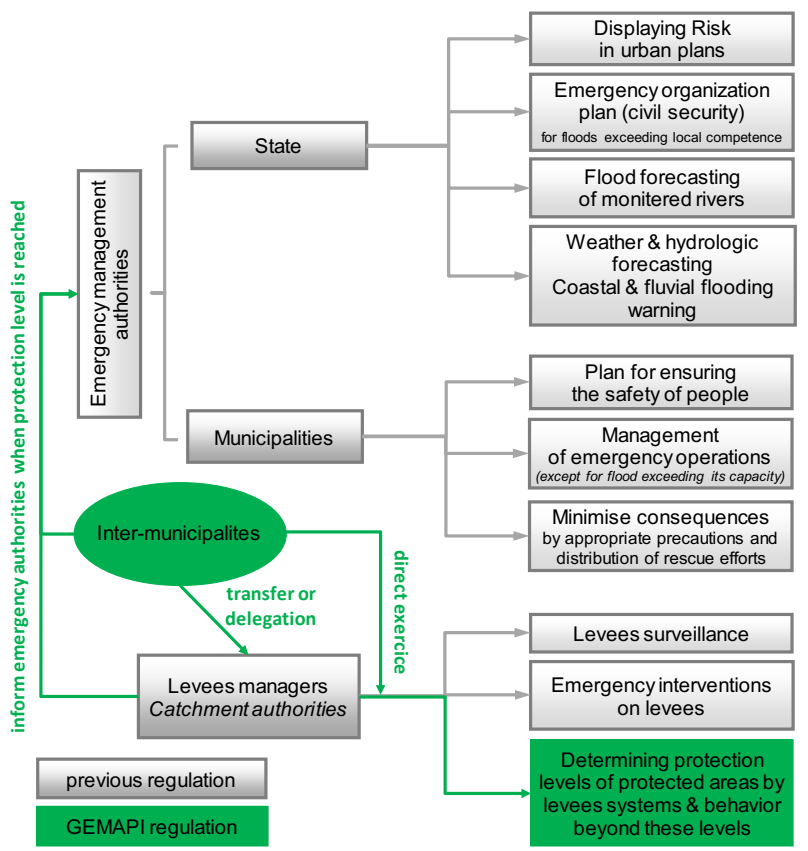

Figure 7. The State's and local authorities' responsibilities

- Flood risk management is locally in the hands of the same GEMAPI authority as management of the water environment, to promote consistent measures. However, the possibility of transfer or delegation of part of the GEMAPI competence may prove a risk in regards of this virtuous objective.

- The regulation is pushing toward management of floods and water environment at a catchment or sub catchment scale, but this may take time to be implemented, as it will rely on local willingness and negotiated agreements.

- It is sometimes difficult to separate what in the regulation is related to organizational governance or technical obligations related to the structures.
- There have been many evolutions in details of the regulation in the last few years, which, as it takes time for them to be applied, makes it difficult for both managers and engineers to appropriate, adopt and apply them.

- Levees are now considered in systems providing a consistent protection of their hinterland, and not as local structures, which is a necessary improvement to the previous regulation. However, in the case of a levee system geographically situated in the territory of two GEMAPI authorities, a formal agreement or a merging will have to be found locally between the different EPCIs.

- The laws now allow the levee system managers to include in their portfolio private levees as well as other structures with a different main purpose, but this also involves local negotiations and agreements, which may be potentially long and difficult.

- The definition of levee systems leaves some room for interpretation: it is easy to define the smallest (elementary) physical levee system providing flood protection to a consistent and contiguous protected area, while it is also possible to define bigger consistent systems (systems of elementary levee systems), possibly also including flood retention structures. Conducting hazard studies with the existing data and methods is challenging enough at the scale of elementary levee systems. Hazard studies at the scale of a system of systems (for example at the scale of all systems under the responsibility of a manager of an important territory) complexify a lot the risk analysis. It will probably be easier to conduct such an ambitious risk analysis once the elementary ones will be available.

- The new category of hydraulic structures, hydraulic installations for the temporary retention of water $(\mathrm{AH})$ clearly have to be considered in regard to their role in flood mitigation. However, for the larger ones, particularly existing multipurpose dams, their role is not limited to one single GEMAPI authority, so their classification as $\mathrm{AH}$ will probably take some time to be settled with all necessary agreements between the different stakeholders.

- A given AH can according to its size and effect on the floods, may need to have either a hazard study as a dam (centred on its structural performance in terms of safety) or as an $\mathrm{AH}$ (centred on its hydraulic performance in terms of flood protection), or as both, or no hazard study at all.

- Although all recent events show that small structures (dams or levees) are likely to fail and potentially have consequences on people and properties, the number of classified structures to be controlled by the State has been decreased with the number and characteristics of classes, as well as the frequency of the different periodical reports. Small structures (dams as well as levees), given their large number and lower performances may pose as high a risk as large dams [Tourment, 2018, 2], and in any case do pose a higher hazard.

- The residual risk (=taking into account the natural hazard and the performance of the system including its failure hazard) has now clearly to be assessed in the 
hazard studies by local managers for levee systems but not for AHs, while it still is a necessary information for them to make decisions and inform other stakeholders.

- The new management organizations will need to adapt fast, including setting up their budget (incomes and expenses) and hiring the adequate staff (number and abilities). Regarding the technical staff, the solution, easy for large organizations, of diluting technical tasks among a wider group of people with multiple activities should be avoided, as hydraulic structures need specialized skills.

We hope this list of advantages and possible improvements of the current regulation can help other countries in the same process of defining a regulation on flood protection structures, and hopefully also help possible future evolutions of the French one. Some countries [Tourment, 2018, 2] in need for a regulation on hydraulic structures have already used the same path, totally or partially, involving a census of the portfolio of structures, a regulation on technical issues and organizing the local governance of structures. Funding is an obvious necessity; contrary to dams who actually, or continuously "produce" something (like hydropower, drinking water or water for irrigation, ...) flood protection structures only "produce" occasional reduction of losses, and so funding relies more on the community. France has adopted a management and funding scheme similar to the one in use in the Netherlands, with local authorities able to raise taxes to fund this public utility service. However, sustaining long term funding remains a delicate issue for a public service whose visible benefits are only avoided damage costs.

\section{References}

1. ICOLD European Club on Levees and Flood Defences (2018). European and US levees and flood defences Characteristics, Risks and Governance. http://dx.doi.org/10.24346/cfbr eurcold2018

2. French Ministry for Sustainable Development, 2009. Burst of a dam, 2 December 1959, Malpasset (Var). https://www.aria.developpement-durable.gouv.fr/wpcontent/files mf/FD 29490 malpasset 1959 ang.pdf

3. Mallet, T. et al (2019). Accidentology of the levees of the Rhône delta from 1840 to the present day. Colloque Digues2019. https://digues2019.inrae.fr/wpcontent/uploads/2019/11/66-Accidentologie.pdf

4. Serra-Llobet, A. et al. (2018). Regulatory flood maps in the US and the EU: Comparing different approaches. I.S.

Rivers https://www.graie.org/ISRivers/docs/papers/2018/23A3 1-005SER.pdf

5. Tourment, R. et al. (2016). Levees, Diversion Canals or FloodExpansion Areas?. 3rd European Conference on Flood Risk Management (FLOODrisk 2016), Oct 2016, Lyon, France. pp.12007, 10.1051/e3sconf/201607 12007. hal-01438211

6. Tourment, R. et al (2016). The risk analysis of levee systems: a comparison of international best practices. 3rd European Conference on Flood RiskManagement (FLOODrisk 2016), Oct 2016, Lyon, France. pp.03009, DOI: 10.1051/03009
7. Tourment, R. et al. (2017). Structures for flood defense and management. in: Floods - Edited by Freddy Vinet, Volume 1- Risk Knowledge, ISTE Press - Elsevier, London + Oxford, UK, p. 193-208

8. Tourment, R. et al. (2018). Lessons learned on the damage on the levees of the Agly river. Analysis of the sand-boils phenomena - Twenty-Sixth International Congress on Large Dams, 4th - 6th July 2018, Vienna, Austria, 31p. https://doi.org/10.1201/9780429465086

9. Tourment, R. (2018) General report of Question 103 "Small Dams and Levees". 26th ICOLD Congress 01/07/2018-07/07/2018, Vienna, Austria. 96 p. 